\title{
Stage IIA Merkel Cell Carcinoma AJCC v7
}

National Cancer Institute

\section{Source}

National Cancer Institute. Stage IIA Merkel Cell Carcinoma A/CC v7. NCI Thesaurus. Code C85894.

Stage IIA includes: T2/T3, pNO, M0. T2: Primary tumor greater than $2 \mathrm{~cm}$ but not more than $5 \mathrm{~cm}$ in maximum dimension. T3: Primary tumor over $5 \mathrm{~cm}$ in maximum dimension. pNO: No regional lymph node metastasis by pathologic examination. MO: No distant metastasis. (AJCC 7th Ed.) 